\title{
Educating Canadians on the Health Risks of Corporal Punishment and
}

\section{Safe and Effective Alternatives}

Jeremy Doucette, Bryanne Harris, and Peter Jaffe

\begin{abstract}
Corporal punishment of children, although banned in 32 countries, is still legal in Canada. Countries which have banned corporal punishment have done so based on their recognition of children as people who have a right to be free from harm. For over two decades, research has outlined the mental and physical health risks of exposing children to corporal punishment. Furthermore, corporal punishment has been found to be ineffective in the long-term, and more effective, safer, and healthier forms of discipline have been presented through research and encouraged by medical doctors and psychologists. This article summarizes these findings and highlights the importance of disseminating education on corporal punishment as Sweden effectively accomplished. It is concluded that Canadian communities must support parents in turning away from corporal punishment and promote the practice of safe and healthy disciplinary alternatives.
\end{abstract}

Keywords: Corporal punishment; spanking; discipline; health; education; safety 
Raising awareness and educating Canadians, principally parents and teachers of young children, on the health risks associated with corporal punishment is a necessary and meaningful endeavour. Many Canadian parents still use corporal punishment towards their children despite the existence of over two decades of literature which outlines how corporal punishment can threaten the healthy development of children (Durrant \& Ensome, 2012). This paper will review Canadian law addressing the corporal punishment of children, and the ban on corporal punishment within 32 countries from around the world, with special consideration given to how bans have impacted Sweden and Kenya. This comparison will set the stage for a discussion of the importance of designing efforts to educate parents on the rights of children, the harm corporal punishment can cause, the long-term ineffectiveness of corporal punishment, and safe and effective disciplinary alternatives.

\section{Corporal Punishment and the Law}

The term corporal punishment is often used interchangeably with the terms spanking, physical punishment, and physical discipline. Corporal punishment includes spanking, which is considered by many to be an open-handed strike to the buttocks, but it can also include hitting other parts of children's bodies and hitting with objects (Ferguson, 2013; Gershoff, 2002).

Section 43 of the Canadian Criminal Code states

Every schoolteacher, parent or person standing in the place of a parent is justified in using force by way of correction toward a pupil or child, as the case may be, who is under his care, if the force does not exceed what is reasonable under the circumstances.

(Department of Justice, Government of Canada, 2013)

Section 43 has been part of Canada's Criminal Code since 1892. Although laws concerning corporal punishment have evolved since 1892 (e.g., the removal of the use of the 
strap in schools in the 1990s), Section 43 remains in the Criminal Code (Axelrod, 2010;

Bernstein, 2004). In 2000, an unsuccessful appeal was made by the Canadian Foundation for Children, Youth and the Law to repeal Section 43 in the Ontario Court. The Foundation then appealed to the Ontario Court of Appeal but was again unsuccessful. Finally, the appeal went to the Supreme Court of Canada, and on July 9, 2004, the Supreme Court determined that Section 43 was not in violation of the Canadian Charter of Rights and Freedoms. Although the appeal was unsuccessful, it did lead to the Supreme Court establishing what constituted as reasonable force under the circumstances (Public Legal Education and Information Service of New Brunswick, 2007). It was established that

1. Only parents may use reasonable physical force, but only for purpose of correction;

2. Teachers may use reasonable force only to remove a child from a classroom or secure compliance with instructions, but not as corporal punishment (Bernstein, 2004);

3. Corporal punishment cannot be used towards children under two years or over twelve years of age (Repeal 43 Committee, n.d.);

4. The use of force on children of any age who are unable to learn from it due to disability or other contextual factors is not protected;

5. Using objects to hit or hitting of the head is unreasonable;

6. Degrading, inhuman or harmful conduct is not protected, including conduct that raises the risk of harm;

7. Only minor corrective force may be used;

8. The physical punishment must be corrective, and cannot stem from a caregiver's frustration or loss of temper;

9. The gravity of the precipitating event is irrelevant; 
10. The question of what is reasonable under the circumstances requires an objective test and must be considered within the context of the case (Bernstein, 2004).

These guidelines have the potential to play an important role in protecting children from harm by way of corporal punishment.

Thirty-two countries throughout the world have taken a stance against corporal punishment by banning it completely. These countries are Sweden (1979), Finland (1983), Norway (1987), Austria (1989), Cyprus (1994), Denmark (1997), Latvia (1998), Croatia (1999), Bulgaria (2000), Israel (2000), Germany (2000), Iceland (2003), Ukraine (2004), Romania (2004), Hungary (2005), Greece (2006), Netherlands (2007), New Zealand (2007), Portugal (2007), Uruguay (2007), Venezuela (2007), Spain (2007), Togo (2007), Costa Rica (2008), Republic of Moldova (2008), Luxembourg (2008), Liechtenstein (2008), Poland (2010), Tunisia (2010), Kenya (2010), Republic of Congo (2010), and South Sudan (2011) (Gershoff, 2013). These countries have defended their ban on corporal punishment based on the growing body of research outlining the potentially harmful consequences of corporal punishment, and the growing conviction that children have the right not to be hit (Durrant, 2008).

\section{The Need for Widespread Education as Demonstrated through Kenya and Sweden}

Bans on corporal punishment have, thus far, lead to different outcomes for different countries. Kenya, which banned corporal punishment completely in 2010, and Sweden, which banned corporal punishment in 1979, are two countries whose experiences are worth contrasting (Gershoff, 2013; Mweru, 2010).

Corporal punishment has been banned in Kenyan schools since 2001, but a study by Maureen Mweru (2010) of Kenyatta University reveals that in 2010, corporal punishment was still taking place in schools. Curran (2001) reported that many teachers defended caning their 
students by referring to Proverbs 13:24 in the Judeo-Christian Bible which states, "He who spares the rod hates his son, but he who loves him is diligent to discipline him". Many teachers also defended corporal punishment based on their observation that students stopped misbehaving immediately after they were caned. The teachers revealed that they had been encouraged to use non-violent disciplinary strategies such as time-out. However, they considered time-out ineffective because there were too many students in each classroom, and putting effort into administering time-out was not feasible. Mweru concluded that the teachers required further support from others within their communities to help with stress reduction, along with education on corporal punishment and safe and effective disciplinary alternatives. These alternatives might be similar to strategies found to be effective in other countries, but they may have to be tailored to the specific needs of teachers, students, and their parents within Kenya. Education should be provided for teachers, but it is also important that other community members receive education as well. For example, dialogue with religious leaders on the dangers of corporal punishment might encourage them to support teachers and parents in choosing disciplinary methods which do not involve hitting (Mweru, 2010).

In 1979, Sweden became the first country to ban corporal punishment. Research on Sweden's experience has revealed that banning corporal punishment, although important, was not sufficient in eliciting cultural change and that extensive educational initiatives throughout the country were necessary. The ban was accompanied by the dissemination of knowledge through many media including the nationwide distribution of a 16-page brochure which was translated into many languages, and the printing of information about the new law on milk cartons (Durrant, 1999). Research has revealed that the percentage of parents who use corporal punishment in Sweden has declined from approximately $95 \%$ in the 1960 s, to approximately $12 \%$ in the 2000 s. 
Through this time, there has also been a significant increase in reporting child abuse, reflecting that the citizens of Sweden have taken a stand against violence towards children (Modig, 2009).

\section{The Negative Impacts of Corporal Punishment}

Many Canadians believe corporal punishment is an unacceptable practice because children have a right to be protected from harm (Department of Justice, Government of Canada, 2013). Research outlining the negative developmental outcomes associated with corporal punishment was introduced in 1990 (Durrant \& Ensome, 2012). In 2005, Murray Straus reported that of 117 studies evaluating corporal punishment, 94\% $(n=110)$ found evidence that corporal punishment was associated with harmful effects, which represents an exceptionally consistent research finding. It has been discovered that being subjected to corporal punishment in early childhood can lead to various negative health and developmental outcomes including aggressive behaviour, mental health difficulties, physical health difficulties, confusion, and damage to the parent-child relationship (Gershoff, 2013;Rose-Krasnor \& Durrant, n.d.; Straus, 2005).

When children are hit by their parents, they are more likely to act aggressively and act out misbehaviours that their parents are trying to prevent (Maguire-Jack, Gromoske, \& Berger, 2012; Straus, 2005). Research studies with child participants over several years found that being spanked at age one was related to more negative behaviours at three years-old, and being spanked at three years-old was related to more negative behaviours at five years-old (Gromoske \& Maguire-Jack, 2012; Lee, Altschul \& Gershoff, 2013). Research has also demonstrated that being spanked during childhood can lead to aggressive tendencies in adolescence, which can appear in the form of bullying or other violent behaviours towards parents, siblings, friends, and dating partners (Durrant, 2008; Ohene, Ireland, McNeely, \& Borowsky, 2006). It is important to recognize that it is not too late for parents to stop spanking their children if they currently do. In 
a study with over 500 parents, a decline in children's problematic behaviours was found once parents who spanked were taught how to discipline in other ways (Durrant \& Ensome, 2012).

Corporal punishment can lead to mental health related difficulties for children. Being physically punished is a scary and stressful experience. This fear does not disappear once the spanking has stopped. Children who experience corporal punishment may feel stress, fear, anxiety, shame, unhappiness, and depression, which can continue throughout childhood and into adulthood (Afifi, Mota, Dasiewicz, MacMillan, \& Sareen, 2012; Straus, 2005). Recent neuroimaging studies suggest that corporal punishment may reduce the brain's gray matter in areas associated with performance on intelligence scales, and it may alter the dopaminergic regions associated with vulnerability to alcohol and other drug abuse (Durrant \& Ensome, 2012).

Corporal punishment can also lead to physical health related difficulties for children. Many parents fail to appreciate how much bigger and stronger they are than their children when administering corporal punishment. Parents who spank their children are seven times more likely than parents who do not spank, to physically assault their children. Far too many Canadian parents engage in the physically abusive behaviour of hitting their children with objects such as belts or paddles. These behaviours can lead to serious injury (Gershoff, 2013).

Spanking children's body parts such as their buttocks can be very confusing for children because they are taught that that part of the body is private and that their body is their own. It is important to teach children that their bodies are their own, that they are special, and should not be forcefully touched or hit. This message must be clear so that children are able to recognize when someone touching their body does not feel right, and are able to express this to an adult they trust (Rose-Krasnor \& Durrant, n.d.).

Spanking and other forms of corporal punishment are associated with poor parent-child 
relationships. Children realize that it is their parents who make them feel scared, hurt, ashamed, or sad when they are hit. Children who are hit may come to believe their parents are scary, dangerous, or untrustworthy (Straus, 2005).

\section{The Ineffectiveness of Corporal Punishment}

Some people advocate for corporal punishment because they believe it works (Mweru, 2010). Some research does show that corporal punishment leads to immediate compliance but no more than what other approaches might bring. Also, non-violent approaches are less likely to result in children yelling, crying, or hitting. Research is clear that corporal punishment is ineffective in the long-term and can lead to negative long-term consequences, whereas other forms of discipline have long-term benefits. This might be difficult to appreciate because no form of discipline usually works with young children at first. All approaches require consistency and repetition (Durrant \& Ensome, 2012; Gershoff, 2002; Straus, 2005). Corporal punishment is ineffective in helping children develop values, care for others, develop responsibility, learn to problem solve, and think independently (Gershoff, 2013).

\section{Safe and Effective Disciplinary Alternatives}

When choosing a disciplinary approach, a child's safety must be prioritized. To stress the importance of safety in discipline, the acronym "SAFE" will be used to outline four components of discipline which research has shown to be both safer and more effective over time than corporal punishment. "SAFE" stands for Setting long-term parenting goals; Acting warmly and achieving structure; Following children's development; and Exploring solutions and reacting (American Academy of Paediatrics, 1998; Canadian Paediatric Society, 2004; Council of Europe Publishing, 2007; Crary, n.d.; Davidov, Grusec, \& Wolfe, 2012; Durrant, 2008; Passini, Pihet, \& Favez, 2013). 
Setting long-term parenting goals is an important first step to effective discipline(Durrant, 2008). In setting long-term goals, it is important for parents to recognize that they set a standard for appropriate behaviour as role models to their children (Bandura, 1971).

Research is clear that discipline is most effective when parents encourage their children to behave well and praise them when they do (Collaborative for Academic, Social, and Emotional Learning, n.d.). Parents should also strive to express love towards their children and validate their feelings. When parents help their children recognize and express their own feelings, they help their children develop the ability to express their needs through healthy strategies as opposed to misbehaving. Helping children understand their feelings can help them to selfregulate their emotions and behaviorsas well as increase feelings of autonomy. (Crary, n.d.; Davidov, Grusec, \& Wolfe, 2012). Additionally, providing children with structure by setting realistic and consistent rules and expectations can prevent misbehaviours from occurring (Baumrind, 1996; Council of Europe Publishing, 2007).

Understanding children's development and developmental needs will help parents discipline effectively. By gaining education on child development, parents of young children can appreciate that their children require role modelling, ongoing support, and the freedom to make small-scale decisions (Canadian Paediatric Society, 2004; Child Welfare League of Canada, n.d.; Collaborative of Academic, Social, and Emotional Learning, n.d.).

Successful discipline requires both proactive (increasing positive behaviours) and reactive (reducing misbehaviours) strategies (American Academy of Paediatrics, 1998; Passini, Pihet, \& Favez, 2013). Children will make mistakes. Sometimes they will learn from their mistakes without intervention from their parents, but there are times parents will have to intervene. Parents might be able to effectively respond to misbehaviours by exploring if their 
children's needs are being met and by meeting their needs if they are not. If children's needs are met but they continue to act out a particular misbehaviour, parents might consider responding reactively (Council of Europe Publishing, 2007).

Both time-out and the removal of privileges are reactive strategies which have been supported by parents, children's advocacy groups, child-care experts, and researchers (Morawska, \& Sanders, 2011; Passini, Pihet, \& Favez, 2013; Warzak, Floress, Kellen, Kazmerski, \& Chopko, 2012). Although time-out and the removal of privileges can be effective in reducing misbehaviours, they can also be misused (Morawska \& Sanders, 2011). The American Academy of Paediatrics suggests that for these strategies to be effective, parents need to very clearly explain to their children which behaviour was unacceptable, why it was unacceptable, and how it can negatively impact others. Problem solving must be performed immediately and consistently if (or when) the misbehaviour occurs. Parents must also appreciate that these approaches often require practice over time before a change in long-term behaviour will occur (Flaskerud, 2011).

\section{Summary and Conclusion}

Law reform is an important step in protecting children from corporal punishment, but as demonstrated through Kenya's and Sweden's experiences, extensive education is required in helping parents and teachers use safe and effective forms of discipline in place of corporal punishment. Sweden has shown that educating the public on children's rights and the risks of hitting children can encourage communities to take a stand against all forms of child maltreatment. Learning of the successes and limitations experienced by other countries which have banned corporal punishment can inform Canadians of effective ways to educate and support parents, teachers, and other caregivers of young children. Although disciplinary alternatives can be effective in keeping children safe and preventing misbehaviours, change does not occur 
immediately, and parents must be consistent in their administration of discipline. This is not simple, as parenting can be a very stressful experience. Parents must receive support from other parents, family members, teachers, and professionals in turning away from corporal punishment and using safe and effective alternatives instead. Together, Canadians can strive to ensure that children develop in environments free from violence and abundant in warmth, structure, and understanding. 


\section{References}

Afifi, T., Mota, P., Dasiewicz, P., MacMillan, H., \& Sareen, J. (2012). Physical Punishment and Mental Disorders: Results from a Nationally Representative US Sample. Pediatrics, 130(2), 1-9.

American Academy of Paediatrics. (1998). Guidance for Effective Discipline. Pediatrics, 101(4), 723-728.

Axelrod, P. (2010). Banning the Strap: The End of Corporal Punishment in Canadian Schools. Canadian Historical Review 91(2), 261-285.

Bandura, A. (1971). Social learning theory. New York: General Learning Press.

Baumrind, D. (1996). The discipline controversy revisited. Family Relations, 45, 405-415.

Bernsein, M. (2004). The Decision of the Supreme Court of Canada Upholding the Constitutionality of Section 43 of the Criminal Code of Canada: What This Decision Means to the Child Welfare Sector. OACAS Journal, 48(2), 2-14.

Canadian Paediatric Society.(2004). Paediatric Child Health, 9(1), 37-41.

Child Welfare League of Canada. Encouraging good behaviour: Discipline without hurting. Retrieved July 4, 2013, from http://www.york.ca/NR/rdonlyres/b63sil4mtekugwneijso35rheqcvzo215o7hsbhg4p4nqfgn xrkcn65aluetgupgloqz2ri6hzn6monlzdgfbr27db/Discipline+Without+Hurting+- +Eng lish.pdf

Collaborative for Academic, Social, and Emotional Learning. Tools for Families. Retrieved July 4, 2013, from http://casel.org/in-schools/tools-for-families/ 
Council of Europe Publishing. (2007). Abolishing Corporal Punishment of Children: Questions and Answers. Retrieved July 4, 2013, fromhttp://www.coe.int/t/dg3/children/pdf/Ques tionAnswer_en.pdf

Crary, E. Tantrums as a Teaching Tool: 5 Ways to Help Children Learn. Retrieved July 4, 2013, from http://www.parentingpress.com/brochure/temper.pdf

Curran, K.A. (2001). Cross-cultural comparison between Finland and the United States on the attitudes and practices of corporal punishment and abuse. Order No. AAI3031512, Dissertation Abstracts International Section A: Humanities and Social Sciences, 3688.

Davidov, M., Grusec, J. E., \& Wolfe, J. L. (2012). Mother's knowledge of their children's evaluations of discipline: The role of type of discipline and misdeed, and parenting practices. Merrill-Palmer Quarterly, 58(3), 314-340.

Department of Justice, Government of Canada. (2013). Family Violence Laws. Retrieved July 4, 2013, fromhttp://www.justice.gc.ca/eng/cj-jp/fv-vf/laws-lois.html

Durrant, J. (1999). Evaluating the Success of Sweden's Corporal Punishment Ban. Child Abuse \& Neglect, 23(5), 435-448.

Durrant, J. E. (2008). Physical punishment, culture and rights: Current issues for professionals. Journal of Developmental and Behavioral Pediatrics, 29, 55-66.

Durrant, J. \& Ensome, R. (2012). Physical punishment of children: lessons from 20 years of research. CMAJ, 184(12), 1373-1339.

Ferguson, C. (2013). Spanking, corporal punishment and negative long-term outcomes: A metaanalytic review of longitudinal studies. Clinical Psychology Review, 33, 196-208

Flaskerud, J. (2011). Cultural Competence Column: Discipline and Effecitve Parenting. Issues in Mental Health Nursing, 32, 82-82. 
Gershoff, E. T. (2002). Corporal punishment by parents and associated child behaviors and experiences: A meta-analytic and theoretical review. Psychological Bulletin, 128, 539- 579.

Gershoff, E. T. (2012). Hitting Close to Home: Teaching About Spanking. In D. S. Dunn, R. A. R. Gurung, K. Z. Naufel, \& J. H. Wilson. (Eds.), Controversy in the Psychology Class room: Using Hot Topics to Foster Critical Thinking. Washington: American Psychological Association.

Gromoske, A. \& Maguire-Jack, K. (2012). Transactional and Cascading Relations Between Early Spanking and Children's Social-Emotional Development. Journal of Marriage and Family, 74, 1054-1068.

Lee, S. J., Altschul, I., \& Gershoff, E. T. (2013). Does warmth moderate longitudinal associations between maternal spanking and child aggression in early childhood? Developmen tal Psychology.

Maguire-Jack, K., Gromoske, A. N., \& Berger, L. M. (2012). Spanking and child development during the first 5 years of life. Child Development, 83(6), 1960-1977.

Modig, C. (2009). Never Violence - Thirty Years on from Sweden's Abolition of Corporal Punishment. Government Offices of Sweden and Save the Children Sweden 2009.

Morawska, A. \& Sanders, M. (2011). Parental Use of Time Out Revisited: A Useful or Harmful Parenting Strategy? Journal of Child and Family Studies, 20, 1-8.

Mweru, M. (2010). Why are Kenyan teachers still using corporal punishment eight years after a ban on corporal punishment? Child Abuse Review, 19(4), 248-258.

Ohene, S., Ireland, M., McNeely, C., \& Borowsky, I. W. (2006). Parental expectations, physical punishment, and violence among adolescents who score positive on a psychosocial screening test in primary care. Pediatrics, 117, 441-447. 
Passini, C., Pihet, S., \& Favez, N. (2013). Assessing Specific Discipline Techniques: A MixedMethods Approach. Journal of Child and Family Studies.

Public Legal Education and Information Service of New Brunswick. (2007). Spanking and Disciplining Children: What You Should Know About Section 43 of the Criminal Code. Fredericton, New Brunswick. Retrieved from http://www.legal-info- legale.nb.ca/en/spank ing_disciplining_children

Repeal 43 Commitee. Section 43 of the Criminal Code. Rerieved July 4, 2013, from repeal43.org Rose-Krasnor, L. \& Durrant, J. Spanking: Should I or Shouldn't I? Family \& Children's Services St. Thomas \& Elgin. Retrieved from http://www.caselgin.on.ca/abuse-spanking.html Straus, M. A. (2005). Children should never, ever, be spanked no matter what the circumstances. In Loseke, D. R., Gelles, R. J., \& Cavanaugh, M. M. (Eds.), Current Controversies about Family Violence $\left(2^{\text {nd }}\right.$ ed, p. 137-157). Thousand Oak, CA: Sage. 
